\title{
THE RELEVANCE OF THE APPLICATION OF THE PRESIDENTIAL THRESHOLD AND THE IMPLEMENTATION OF SIMULTANEOUS ELECTIONS IN INDONESIA
}

\author{
Rizki Bagus Prasetio*, Febri Sianipar** \\ Research and Development Board for Law and Human Rights \\ *The Ministry of Law and Human Rights of the Republic of Indonesia, Jakarta \\ **General Election Commission of the Republic of Indonesia, Jakarta \\ Corresponding email: rizkibagusprasetyo@gmail.com
}

Paper received on: 31-03-2021; Revised on: 03-05-2021; Approved to be published on: 04-05-2021

DOI: http://dx.doi.org/10.30641/dejure.2021.V21.267-284

\begin{abstract}
This research is intended to discuss the relevance of the application of presidential threshold and the implementation of simultaneous general elections in Indonesia. The concept of simultaneous general elections is the implementation of legislative and executive elections which are carried out simultaneously. The implementation of the first simultaneous general elections in Indonesia was motivated by a request for a judicial review of Law Number 42 Year 2008 concerning the Election of the President and Vice President. The Constitutional Court issued the Constitutional Court Decision Number 14/PUU-IX/2013 with the decision granting part of the request which later gave birth to the implementation of simultaneous elections in Indonesia starting in 2019. However, from the various articles that were reviewed, there was one article that was not decided by the Constitutional Court, namely regarding the presidential threshold. The Constitutional Court is of the opinion that the regulation regarding the presidential threshold is an open legal policy for the legislature. This paper is a normative legal research, with conceptual approach and statute approach to find answers to existing problems. The research source used is secondary data consisting of primary legal materials and secondary legal materials as explanation for primary legal materials. From the results of this research, it was found that the simultaneous elections and the presidential threshold were not compatible. On the one hand, the presidential threshold aims to simplify the number of parties.
\end{abstract}

Keywords: relevance; simultaneous general election; presidential threshold

\section{INTRODUCTION}

As one of the implementations of democratic practice, the General Election is carried out in order to realize a government system which has sovereignty of the people. In Indonesia, the concept of democratic governance is explicitly stated in Article 1 Paragraph (2) of the 1945 Constitution of the Republic of Indonesia which states that sovereignty is in the hands of the people and is implemented according to the Constitution. The emphasis on this basic idea is that the people are the holder of the highest sovereignty. Therefore, the government is organized from, by, and for the people or known as the normative democratic approach ${ }^{1}$. This statement is in line with the opinion of Padmo Wahyono who states that democratic government is government by

Oki Wahju Budijanto, "PEMENUHAN HAK POLITIK WARGA NEGARA DALAM PROSES PEMILIHAN KEPALA DAERAH LANGSUNG," Jurnal Penelitian Hukum De Jure 16 (2016). Hal 294 the people based on the matters of their state on the power of the people so that the people are sovereign ${ }^{2}$. The concept of democratic sovereignty in the hands of the people means that the owner of the highest power is the people. People's power is channeled and administered according to the mechanism of the constitutional procedure of the 1945 Constitution ${ }^{3}$. Previously, it was known that the people could not fully exercise their sovereignty, because the electoral system was not implemented openly. With an election system that gives the people the right to choose their leaders and representatives, it will certainly improve the quality of democratic life in Indonesia ${ }^{4}$.

C. Noviati, "Demokrasi dan Sistem Pemerintahan," Jurnal Konstitusi 10, no. 2 (2013): 333-354.

3 Syaifulloh, "Kesadaran Pluralisme Dalam Praktik Demokrasi Pancasila," Jurnal IDe (Inspirasi Demokrasi) Vol. o8 (2019). Hal 8

4 Made Oka Cahyadi Wiguna, "Pentingnya Prinsip Kebijaksanaan Berdasarkan Pancasila Dalam Kehidupan Hukum Dan Demokrasi Indonesia," Jurnal 
Commonly, in a country that adopts a democratic system, the implementation of general elections is carried out to elect public officials in the legislative and executive fields, both at the central and regional levels. 5 . In Indonesia, since independence until now, general elections have been held 12 times. However, the 2019 general elections were carried out with a different mechanism $^{6}$ compared to previous general elections such as in 1955, 1971, 1977, 1982, 1987, 1992, 1997, 1999, 2004, 2009 and 20147.

In the 2019 general elections, for the first time Indonesia adopted the simultaneous general election mechanism by electing members of the House of Representatives, Regional Representative Council, Regional House of People's Representative, as well as the President and Vice President at the same time. The implementation of the simultaneous general elections was motivated by the existence of a request for a judicial review of Law Number 42 Year 2008 concerning the Election of the President and Vice President against the 1945 Constitution of the Republic of Indonesia which was submitted by Effendi Gazali ${ }^{8}$ together with the Community Coalition to the Constitutional Court.

In the process of submitting the judicial review, there are several articles in Law Number 42 Year 2008 concerning the General Election of the President and Vice President which have been reviewed for their constitutionality, such as:

Article 3 Paragraph (5) of Law of President and Vice President General Election.

President and Vice President general elections are held after the general elections for members of the House of Representatives, the Regional Representative Council, and the Regional House of People's Representative.

Ilmiah Kebijakan Hukum Volume 15, no. 1 (2021). Hal 730

5 Achhmad Edy Subiyanto, "Pemilihan Umum Serentak Yang Berintegritas Sebagai Pembaruan Demokrasi Indonesia," Jurnal Konstitusi 17 (2020). Hal 358

6 Pasal 347 ayat (1) Undang-Undang Nomor 7 Tahun 2017 tentang Pemilihan Umum

7 Ratnia Solihah, "Peluang Dan Tantangan Pemilu Serentak 2019 Dalam Perspektif Politik," Jurnal Ilmiah Ilmu Pemerintahan 3 (2018). Hal 78

8 Rubian Ariviani et al., "Analisis Putusan Mahkamah Konstitusi Nomor 14/Puu-Xi/2013 Berkaitan Dengan Pemilihan Umum Serentak Di Indonesia," Diponegoro Law Review 5, no. 4 (2016). Hal 2
Article 9 of Law of President and Vice President General Election.

Candidate Pairs shall be nominated by Political Parties or Coalition of Political Parties participating in the general election who meet the requirements for obtaining seats of at least $20 \%$ (twenty percent) of the total seats in the House of Representatives or obtaining $25 \%$ (twenty-five percent) of the national valid votes in the general election for members of the House of Representatives, before the implementation of the President and Vice President General Election.

Article 12 of Law of President and Vice President General Election.

(1) Political Parties or Coalition of Political Parties may announce candidates for President and/or candidates for Vice President in the general election campaign for members of the House of Representatives, the Regional Representative Council, and the Regional House of People's Representative.

(2) Presidential candidates and/or vicepresidential candidates announced by Political Parties or Coalition of Political Parties as referred to in paragraph (1) must have obtained written approval from the candidate concerned.

Article 14 Paragraph (2) of Law of President and Vice President General Election.

The registration period as referred to in Article 13 is a maximum of 7 (seven) days as of the national determination of the results of General Election for members of the House of Representatives.

Article 112 of Law of President and Vice President General Election.

Voting for the President and Vice President General Election shall be held no later than 3 (three) months after the announcement of the results of the general elections for members of the House of Representatives, the Regional Representative Council, the Provincial Regional House of People's Representative, and the Regional House of People's Representative

In the application for a judicial review, the petitioner emphasized the original intent of Article 22E of the 1945 Constitution of the Republic of Indonesia with the argument ${ }^{9}$ that

9 Poin 5 (lima) Fundamentum Petendi Permohonan Pemohon dalam Putusan Mahkamah Konstitusi 
the nonsimultaneous legislative and presidential general election mechanisms disturb the right of citizens to vote efficiently and intelligently in terms of the use of time, energy and costs for exercise their voting rights. In addition, the implementation of elections more than once has had many detrimental consequences for the constitutional rights of citizens. Especially in relation to the political participation of citizens.

Furthermore, according to the petitioner, although basically in the implementation of general elections, citizens still have various reasons not to exercise their voting rights, with general elections being held simultaneously, each general election can get the highest voter participation among the General Elections for the House of Representatives, Regional Representative Council, and the Regional House of People's Representative, as well as President and Vice President General Elections.

Therefore, on the application for a judicial review, the Constitutional Court issued the Constitutional Court Decision Number 14/PUUIX/2013 with commands that granted part of the application submitted, namely stating that Article 3 Paragraph (5), Article 12 Paragraph (1) and Paragraph (2), Article 14 Paragraph (2), and Article 112 of Law Number 42 Year 2008 concerning the General Election of the President and Vice President are contrary to the 1945 Constitution of the Republic of Indonesia and do not have binding legal force, with consideration of the original intent of Article 22E Paragraph (2) of the 1945 Constitution of the Republic of Indonesia and the efficiency of general election administration ${ }^{10}$. Thus, general elections in Indonesia become necessary to be held simultaneously.

However, apart from several parts of the application submitted by the petitioner above, there was one article that was not decided by the Constitutional Court, namely Article 9, which related to the presidential threshold. For Presidential and Vice-Presidential Candidates, in terminology, the presidential threshold is the minimum number of seats and votes that a political party or coalition of political parties must obtain in the legislative general election in order to nominate presidential and vice-presidential

Nomor 14/PUU-XI/2013.

1o Pertimbangan hukum Hakim Mahkamah Konsitusi dalam Putusan MK Nomor 14/PUU-IX/2013 candidates ${ }^{11}$.

The argument of the Constitutional Court of not canceling the article that contains the provision of presidential threshold is that the regulation regarding the presidential threshold is an open legal policy for the legislature. The Constitutional Court left the provision regarding the presidential threshold to the legislature, whether the presidential threshold can be applied or not really depends on the political will of the legislature. Whereas the petitioner argued that holding simultaneous general elections will avoid conflicts of interest in party votes in the presidential nomination. Such decisions of the Constitutional Court are also contained in several decisions such as the Constitutional Court Decision Number 5152-59/PUU-VI/2008 and the Constitutional Court Decision Number 53/PUU-XV/2017.

By holding legislative and presidential general elections simultaneously, it should have implications for the elimination of the presidential threshold system. Considering that each political party will only know the number of votes it has when the general election is over, while the presidential election is conducted simultaneously with the legislative election. Thus, with such a position, all political parties should be in the same position, namely the absence of position of majority or minority vote acquisition. The concept of presidential threshold actually creates legal uncertainty on the simultaneousness of the general election itself because it is no different from general elections that are not held simultaneously.

According to Benny $\mathrm{K}$ Harman, the presidential threshold will limit the emergence of alternative figures in the contestation for the election of President and Vice President ${ }^{12}$. The Law of General Election should facilitate the emergence of alternative candidates so that the electoral competition can increase. This includes increasing the participation and quality of the Presidential and Vice-Presidential Candidates ${ }^{13}$.

" Abdurrohman, "Presidential Threshold Dalam Pemilu Di Indonesia , Perspektif Imam Al-Mawardy" (Universitas Islam Negeri Sunan Ampel, 2018). Hal 74

12 Abdul Ghoffar, "Problematika Presidential Threshold : Putusan Mahkamah Konstitusi Dan Pengalaman Di Negara Lain Dispute on Presidential Threshold : Decisions of the Constitutional Court and Other Countries ' Experiences," Jurnal Konstitusi 15, no. 3 (2018): 480-501.

13 Gibran Maulana Ibrahim, "Tolak Presidential 
From the facts that the researchers has described above, the concept of the presidential threshold in simultaneous general elections is an interesting thing to be discussed and studied further. Therefore, the aim of this paper is to study how the relevance or relationship of the presidential threshold concept with the implementation of simultaneous general elections in Indonesia is.

\section{RESEARCH METHOD}

This research is a normative legal research with a conceptual approach and a statute approach. Basically, normative legal researches examine legal rules and legal principles ${ }^{14}$. Normative researches attempt to find legal rules, legal principles, and legal doctrine that will be used to answer the legal issues faced ${ }^{15}$. The legal issue in this paper is related to the context of the General Election and the implementation of the Presidential threshold. The data in this study is secondary data. The data was obtained from a literature study consisting of primary legal materials and secondary legal materials. Primary legal materials are none other than the main legal materials that are authoritative in nature consisting of laws and regulations ${ }^{16}$ governing the implementation of general elections in Indonesia which have been in effect from time to time, such as Law Number 23 Year 2003 concerning the General Election of the President and Vice President, Law Number 42 Year 2008 concerning Presidential and VicePresidential Elections and Law Number 7 Year 2017 concerning General Elections. Meanwhile, secondary legal materials are legal materials that support and strengthen primary legal materials, consisting of doctrines, scientific research results from experts and news which is of course relevant ${ }^{17}$ to the implementation of the Simultaneous General Election and the implementation of the Indonesian

Threshold, Demokrat: Membatasi Capres Alternatif," last modified 2017, https://news.detik.com/ berita/d-3567236/tolak-presidential-thresholddemokrat-membatasi-capres-alternatif.

14 Bagir Manan, "Penelitian Terapan Di Bidang Hukum", (Disampaikan Pada Lokakarya Peranan Naskah Akademis Dalam Penyusunan Peraturan PerundangUndangan)," Badan Pembinaan Hukum Nasional, Jakarta (1993).

15 Peter Mahmud Marzuki, Penelitian Hukum (Jakarya: Kencana, 2010). Hal 35

16 Ibid.

${ }_{17}$ Ibid.
Presidential threshold. Both primary and secondary legal materials that had been obtained were then selected according to their validity and then analyzed using qualitative analysis method that emphasize a more normative analysis with deductive thinking method to answer the legal issue in this research.

\section{DISCUSSION AND ANALYSIS}

\section{A. The Development of Simultaneous General Elections and Presidential Threshold in Indonesia}

Usually in a presidential government system, legislative and executive elections are carried out through a general election mechanism. However, it is believed that the implementation of legislative and executive elections separately will not support a more effective and efficient implementation of democracy. This can be seen in terms of time, the amount of costs, and the personnel of the election organizers if the elections are held at different times. This was also stated by the Constitutional Court, that the implementation of executive elections after the legislative elections was not able to become a means of transforming social change in the desired direction nor did it strengthen the presidential system to be established based on the 1945 Constitution of the Republic of Indonesia ${ }^{18}$. In addition, in order to prevent a divided government, which is commonly seen as the weakness of the presidential system when the president and parliament are controlled by different political forces, the presidential system combined with multi-parties with high political fragmentation and ideological polarization has the potential to cause paralysis due to the executive-legislative deadlock which has an impact on political instability ${ }^{19}$. The existence of deficiencies or weaknesses of separate election administration makes the need for holding elections simultaneously.

The Constitutional Court Decision Number 14/PUU-XI/2013 is the first step towards a simultaneous election regime. Commonly, in a presidential government system there are two

\footnotetext{
18 Sukimin Sukimin, "Pemilihan Presiden Dan Wakil Residen Berdasarkan Undang-Undang Republik Indonesia Nomor 7 Tahun 2017 Tentang Pemilihan Umum," Jurnal Usm Law Review 3, no. 1 (2020). Hal 123

19 Yuliyanto Yuliyanto, "Transformasi Model Pelaksanaan Pemilihan Kepala Daerah Serentak," Jurnal Penelitian Hukum De Jure 17, no. 1 (2017): 57.
} 
separate elections, namely the election to elect the executive and the election to elect the legislature. The difference in the timing of this election has implications for the distribution of power in parliament and also affects the governability (effectiveness) of the government because it involves the working relationship between the two institutions ${ }^{20}$. This is in line with the coattail effect thesis based on Shugart's thesis which was applied in Brazil, that after they synchronized the implementation of the executive and legislative elections, it shows that this factor can overcome the problem of disharmony relations between the executive and legislature ${ }^{21}$.

Reflecting on the experience in Indonesia so far, there are several strong reasons to say that simultaneous elections have a certain urgency ${ }^{22}$. First, in terms of the required budget efficiency. By holding elections at the same time, the budget needed to hold elections can be saved. Second, in terms of the effectiveness of holding elections. By holding elections at the same time, of course, it is very effective both for the time of implementation and the energy needed to carry out the election. Third, to reduce monetary political turmoil. By holding elections simultaneously, this will have an impact on reducing or minimizing efforts to implement monetary and political practices that are increasingly occurring in the implementation of elections. Holding elections at different times will not only bring huge costs to the country, but also increase political costs. Simultaneous elections certainly have an influence on the executive electoral system and the arrangement of this electoral system so that post-election it is able to establish a stable government system in a multi-party presidential system and congruent relationship between the executive and the legislature. Findings in various researches, especially from the multi-party presidentialism system in Latin America, show that the combination of an electoral system with a plurality formula with simultaneous legislative elections tends to help simplify the party system. But, it depends on the number of presidential candidates who compete. If there are many presidential

\footnotetext{
${ }_{20}$ Noviati, "Demokrasi Dan Sistem Pemerintahan."

${ }^{21}$ Solihah, "Peluang Dan Tantangan Pemilu Serentak 2019 Dalam Perspektif Politik." hal 82

${ }_{22}$ Jantapar Sinamora, "Menyongsong Rezim Pemilu Serentak," Jurnal RechtsVinding 3, no. 4 (2019): 1-18.
}

candidates, the reductive impact of the plurality system on the legislative party system tends to fade $^{23}$. In addition, simultaneous elections can be used as an alternative for political and government changes. It is said so because it can become an effort to overcome various existing government problems, such as ${ }^{24}$ : (i) becoming the basis for the realization of a strong and stable presidential government system; (ii) facilitating the emergence of a simplification of the party system, namely by providing incentives for political parties in establishing a democratic and sustainable political culture and institutionalization through alliances, coalitions, associations and/or mergers; (iii) promoting the establishment of a more effective parliament; (iv) creating a simpler electoral system, short time and low cost in legislative and presidential elections; (v) creating space for voter participation in elections based on local and national issues; (vi) in order to realize these objectives, the presidential election system of runoff with a reduced threshold (conditional majority) becomes the main choice. With the condition that the President and Vice President are elected in the first round, if they can get $45 \%$ of the votes with a $5 \%$ gap, or $40 \%$ of the votes with a $10 \%$ gap from the second candidates who are their rivals. In addition, the Simultaneous General Elections have an impact on countries in the world, namely reducing the budget for election expenditures, consolidating national identities, stabilizing the state and government, and minimizing constitutional disturbances in public life ${ }^{25}$.

Since the 2004 elections, the president and vice president are directly elected by the people in one pair ${ }^{26}$. The rules for implementing the elections in that year were Law Number 23 Year 2003 concerning the General Election of the President and Vice President which also determined the

23 Septi Nur Wijayanti dan Titin Purwaningsih, Laporan Akhir Tahun Pertama Penelitian Hibah Bersaing: Desain Pemilihan Umum Nasional Serentak Dalam Perspektif Hukum Dan Politik, 2015. Hal 51

${ }^{24}$ Ibid.

25 Bashir Ahmad Wagay, “'“Simulatenous Elections and India Democracy: A Hanging Fruit Requiring Safer Hands to Pluck It"," Scholarly Research Journal for Interdisciplinary Studies 9, no. 44 (2018): 10162-10163.

26 Republik Indonesia, Undang-Undang Nomor 23 Tahun 2003 Tentang Pemilihan Umum Presiden Dan Wakil Presiden, 2003. Lihat Pasal 6A ayat (1) UUD 1945 jo Pasal 1 angka 
presidential threshold for the first time in terms of the nomination of the President and Vice President pair.

Table 1. Presidential Threshold Since Direct Election of President and Vice President

\begin{tabular}{|c|c|c|c|c|}
\hline \multirow[b]{2}{*}{ Year } & \multirow[b]{2}{*}{ Legal Basis } & \multicolumn{2}{|c|}{ Presidential Threshold } & \multirow[b]{2}{*}{ Description } \\
\hline & & $\begin{array}{c}\text { Votes of the } \\
\text { House of } \\
\text { Representatives }\end{array}$ & $\begin{array}{c}\text { National } \\
\text { Valid } \\
\text { Votes } \\
\end{array}$ & \\
\hline 2004 & $\begin{array}{l}\text { Law No. } 23 \\
\text { Year } 2003 \text { on } \\
\text { the General } \\
\text { Election of } \\
\text { the President } \\
\text { and Vice } \\
\text { President, } \\
\text { Article } 5 \\
\text { paragraph } \\
\text { (4) }\end{array}$ & $15 \%$ & $20 \%$ & $\begin{array}{l}\text { Election is } \\
\text { carried out in } \\
\text { two stages }\end{array}$ \\
\hline 2009 & $\begin{array}{l}\text { Law No. } 42 \\
\text { Year } 2008 \\
\text { on General } \\
\text { Election of } \\
\text { the President } \\
\text { and Vice } \\
\text { President, } \\
\text { Article } 920\end{array}$ & $20 \%$ & $25 \%$ & $\begin{array}{l}\text { Election is } \\
\text { carried out in } \\
\text { two stages }\end{array}$ \\
\hline 2014 & $\begin{array}{l}\text { Law No. } 42 \\
\text { Year } 2008 \\
\text { on General } \\
\text { Election of } \\
\text { the President } \\
\text { and Vice } \\
\text { President, } \\
\text { Article } 920\end{array}$ & $20 \%$ & $25 \%$ & $\begin{array}{l}\text { Election is } \\
\text { carried out in } \\
\text { two stages }\end{array}$ \\
\hline 2019 & $\begin{array}{l}\text { Law No. } 7 \\
\text { Year } 2017 \\
\text { on General } \\
\text { Election, } \\
\text { Article 222 }\end{array}$ & $20 \%$ & $25 \%$ & $\begin{array}{l}\text { Elections are } \\
\text { carried out } \\
\text { simultaneously }\end{array}$ \\
\hline
\end{tabular}

As stated in the table above, after the issuance of the Constitutional Court Decision Number 14/PUU-XI/2013, the concept of simultaneous elections was born in Indonesia. Simultaneous elections are also often referred to as concurrent elections. Concurrent elections can be simply defined as an electoral system that holds several elections at the same time simultaneously ${ }^{27}$. These types of elections include executive and legislative elections at various levels known in the country concerned, from the national, regional to local elections. In other words, concurrent elections are held to elect democratic institutions

${ }^{27}$ Eko Noer Kristiyanto, "Pelaksanaan Pemilihan Kepala Daerah Serentak Di Indonesia: Studi Di Batam,” Jurnal Penelitian Hukum De Jure 17, no. 1 (2017). Hal. 50. simultaneously at the same time ${ }^{28}$. In practice, the design that is often used in concurrent elections is to combine executive and legislative elections.

The implementation of simultaneous elections in Indonesia was born as a result of judicial review of several provisions in Law Number 42 Year 2008 against the 1945 Constitution of the Republic of Indonesia. In the decision Number 14/ PUU-XI/2013, the Constitutional Court stated that the legislative elections and executive elections shall be held simultaneously and will be valid for the 2019 elections and subsequent elections ${ }^{29}$. The decision partially granted the judicial review of Law Number 42 Year 2008, namely Article 3 Paragraph (5), Article 12 Paragraph (1) and (2), Article 14 Paragraph (2), and Article 112. However, the Constitutional Court did not grant the judicial review of Article 9.

Table 2. Articles of Law Number 42 Year 2008 on General Election of President and Vice President Which Were Granted/Rejected

\begin{tabular}{|c|c|c|}
\hline Article & Formulation of Norms & Description \\
\hline $\begin{array}{l}\text { Article } 3 \\
\text { paragraph } \\
(5)\end{array}$ & $\begin{array}{l}\text { (5) President and } \\
\text { Vice President } \\
\text { general elections } \\
\text { are held after the } \\
\text { general elections } \\
\text { for members of } \\
\text { the House of } \\
\text { Representatives, } \\
\text { the Regional } \\
\text { Representative } \\
\text { Council, and the } \\
\text { Regional House } \\
\text { of People's } \\
\text { Representative }\end{array}$ & Granted \\
\hline
\end{tabular}

\footnotetext{
28 Apolonaris Gai and Frans Bapa Tokan, "Analisa Dampak Penyelenggaraan Pemilu Serentak Dalam Meningkatkan Kualitas Demokrasi di Indonesia: Studi Kasus Penyelenggraan Pemilu Di Kota KupangProvinsi Nusa Tenggara Timur Tahun 2019," Warta Governare: Jurnal Ilmu Pemerintahan 1 (2020). Hal 112.

29 Lihat Putusan Mahkamah Konstitusi No. 14/PUU$\mathrm{XI} / 2013$ dalam perkara pengujian Undang-Undang No. 42 Tahun 2008 tentang Pemilihan Umum Presiden dan Wakil Presiden terhadap UUD Negara RI Tahun 1945
} 


\begin{tabular}{|c|c|c|}
\hline Article 9 & $\begin{array}{l}\text { Candidate Pairs shall be } \\
\text { nominated by Political } \\
\text { Parties or Coalition } \\
\text { of Political Parties } \\
\text { participating in the } \\
\text { general election who } \\
\text { meet the requirements } \\
\text { for obtaining seats of } \\
\text { at least } 20 \% \text { (twenty } \\
\text { percent) of the total } \\
\text { seats in the House of } \\
\text { Representatives or } \\
\text { obtaining } 25 \% \text { (twenty- } \\
\text { five percent) of the } \\
\text { national valid }\end{array}$ & Rejected \\
\hline & $\begin{array}{l}\text { votes in the general } \\
\text { election for members } \\
\text { of the House of } \\
\text { Representatives, before } \\
\text { the implementation } \\
\text { of the President and } \\
\text { Vice President General } \\
\text { Election }\end{array}$ & \\
\hline Article 12 & $\begin{array}{l}\text { (1) Political Parties } \\
\text { or Coalition of } \\
\text { Political Parties } \\
\text { may announce } \\
\text { candidates for } \\
\text { President and } \\
\text { candidates for } \\
\text { Vice President } \\
\text { in the general } \\
\text { election campaign } \\
\text { for members of } \\
\text { the House of } \\
\text { Representatives, } \\
\text { the Regional } \\
\text { Representative } \\
\text { Council, and the } \\
\text { Regional House } \\
\text { of People's } \\
\text { Representative. } \\
\text { (2) Presidential } \\
\text { candidates and/or } \\
\text { Vice-presidential } \\
\text { candidates } \\
\text { announced by } \\
\text { Political Parties } \\
\text { or Coalition of } \\
\text { Political Parties } \\
\text { as referred to in } \\
\text { paragraph (1) must } \\
\text { have obtained } \\
\text { written approval } \\
\text { from the candidate } \\
\text { concerned. } \\
\end{array}$ & Granted \\
\hline
\end{tabular}

\begin{tabular}{|c|c|c|}
\hline $\begin{array}{l}\text { Article } 14 \\
\text { paragraph } \\
\text { (2) }\end{array}$ & $\begin{array}{l}\text { (2) The registration } \\
\text { period as referred } \\
\text { to in Article } 13 \text { is } \\
\text { a maximum of } 7 \\
\text { (seven) days as } \\
\text { of the national } \\
\text { determination } \\
\text { of the results of } \\
\text { General Election } \\
\text { for members of } \\
\text { the House of } \\
\text { Representatives. }\end{array}$ & Granted \\
\hline Article 112 & $\begin{array}{l}\text { Voting for the President } \\
\text { and Vice President } \\
\text { General Election shall } \\
\text { be held no later than } \\
3 \text { (three) months after } \\
\text { the announcement } \\
\text { of the results of the } \\
\text { general elections for } \\
\text { members of the House } \\
\text { of Representatives, } \\
\text { the Regional } \\
\text { Representative Council, } \\
\text { the Provincial Regional } \\
\text { House of People's } \\
\text { Representative, and the } \\
\text { City/District Regional } \\
\text { House of People's } \\
\text { Representative. }\end{array}$ & Granted \\
\hline
\end{tabular}

In consideration of its decision, the Constitutional Court stated that Article 9 is the threshold for vote acquisition for political parties or coalition of political parties in the form of concrete norms related to the open legal policy owned by the President and the House of Representatives as legislature. Then, this is based on the provisions of Article 6A Paragraph (5) of the 1945 Constitution of the Republic of Indonesia which states that the procedure for conducting the election of President and Vice President is further regulated in law.

In the Decision of the Constitutional Court Number 14/PUU-XI/2013, regarding the issue of the threshold for the nomination of president and vice president, in essence, the Constitutional Court is of the opinion as follows:

a. The Constitutional Court considers that the threshold rule is very discriminatory and cripples the opportunity for political parties or coalitions to nominate candidates, so that its implementation will cause injustice and conflict with the constitution. Because, to determine whether a political party or a coalition of political parties can nominate, the 
public will first determine it in the upcoming legislative elections.

b. The Constitutional Court sees that threshold regulation in the law is an open legal policy for the legislature.

c. Threshold rules prevent democratic, direct, general, free, confidential, honest and fair elections. The Constitutional Court is of the opinion that there is no logical correlation between the requirements of the support of $20 \%$ of the House of Representatives seats or $25 \%$ of the national valid votes that a Party must obtain to nominate a Candidate Pair of President and Vice President. Instead, the party's achievement of these conditions is obtained through a democratic process that is handed over to the people.

The implementation of the threshold resulted in the loss of opportunities and rights of citizens due to parties that did not meet the number of candidates nominated. Therefore, in determining the threshold, one must pay attention to the principles of democracy that are not detrimental to certain groups, especially minorities. The threshold for determining the president must take into account the social diversity reflected in political aspirations ${ }^{30}$. Political participation of citizens through political parties is the responsibility of every citizen's human rights. Article 28E Paragraph (3) of the 1945 Constitution of the Republic of Indonesia stipulates that everyone has the right to freedom of association, assembly and speech.

In fact,if the legislative and executive elections are held simultaneously as implicitly contained in Article 22E Paragraph (2) in conjunction with Article 6A Paragraph (2) of the 1945 Constitution of the Republic of Indonesia, the presidential threshold provision in Article 9 of Law Number 42 Year 2008 loses its relevance. The opinion of Yusril Ihza Mahendra further emphasizes this, that is the existence of simultaneous elections as in the Constitutional Court Decision Number 14/ PUU-XI/2013 causes the threshold as in Article 9 of Law of Presidential Election not applicable. That way, every political party participating in the election can nominate president and vice president. In this case, the positive aspect of this

\footnotetext{
30 Lutfil Ansori, "Telaah Terhadap Presidential Threshold Dalam Pemilu Serentak 2019" 4, no. 1 (2019): 15-27.
}

situation is that all political parties have the same opportunity to nominate Candidates for President and Vice President ${ }^{31}$.

There is an interesting statement from Jimly Asshiddique $^{32}$ that the presidential system has long been embraced in the 1945 Constitution of the Republic of Indonesia. Initially, the drafters of the Constitution envisioned the presidential system as an ideal system. Until now the system is in effect. Presidential system with presidential threshold system indicators.

Meanwhile, according to Refly Harun, the presidential threshold applied to strengthen the presidential system also cannot be confirmed. If the elected president comes from a small party, the cabinet formation must be carried out in a coalition. For example, the Partai Demokrat with a minority vote in 2009 finally invited the Golkar party into the cabinet even though in the presidential election they had to compete ${ }^{33}$. Syamsuddin Harris also states that theoretically the basis of presidential legitimacy in a presidential system does not depend on the political composition of the parliament elected in the legislative elections. The executive and legislative institutions in a presidential system are two different institutions with different legal foundations. Thus, the presidential system will remain effective and strong in government, even though simultaneous elections are held without any presidential threshold requirements for political parties nominating presidential and vicepresidential candidates ${ }^{34}$.

For example, in the 2004 presidential election, Soesilo Bambang Yudhoyono and Jusuf Kalla were only supported by small parties such as the Partai Demokrat, the Partai Bulan Bintang, and the PKPI. At the same time, the competitors were supported by big parties. However, the people chose the SBY-Kalla pair instead. Based on this experience, it appears that people choose the president not because they support the party, but because of the character or candidate nominated by the party. Therefore, increasing the number of candidates will increase the number of choices. The fewer candidates listed on the ballot, the more

\footnotetext{
${ }^{31}$ Lihat alasan Pemohon dalam Putusan Mahkamah Konstitusi No. 108/PUU-XI/2013

32 Jimly Asshiddiqie, Hukum Tata Negara Dan Pilar-Pilar Demokrasi (Jakarta: Sinar Grafika, 2011). Hlm 97

33 Ibid

34 Lutfil Ansori, Op.cit., hlm. 22-23.
} 
likely a good leader will be chosen.

The opinion which says that presidential threshold can strengthen the presidential system, simplify the party system and assist in selecting the Presidential and Vice-Presidential Candidates is not entirely correct. According to Syamsuddin Harris, theoretically the basis of a President's legitimacy in a presidential system scheme is not determined by the political formation of the parliament as a result of the legislative elections. The presidential and parliamentary institutions in a presidential system are two separate institutions that have different legitimacy bases ${ }^{35}$. According to Refly Harun, the application of presidential threshold to strengthen the presidential system also cannot be proven. If the elected President comes from a small party, the cabinet formation will also be carried out with a coalition ${ }^{36}$. In addition, the opinion that says that the threshold simplifies party is also incorrect. The reason is that the General Election Commission strictly selects the political parties participating in the election, so that the political parties that have gone through strict verification are the political parties participating in the election, then they nominate candidates for President and Vice President. The selection of political parties participating in the general election conducted by the General Election Commission is a form of simplification of the party system ${ }^{37}$. Setting a threshold automatically reduces the meaning of elections as a fair and democratic political mechanism in determining the nation's leaders, and it has implications for the quality of people's political participation and efforts to protect voters' rights ${ }^{38}$.

As described above, the Constitutional Court Decision Number 14/PUU-XI/2013 not only gave birth to simultaneous elections in Indonesia but also related to the threshold for vote acquisition for political parties or coalitions of political parties which was declared by the Constitutional Court as a concrete norm with open legal policy. In addition

35 Syamsuddin Harris sebagaimana dikutip oleh Lutfil Ansori, Ibid., hlm. 23.

36 Ibid.

37 Ibid.

${ }^{38}$ I Dewa Made and Putra Wijaya, "Mengukur Derajat Demokrasi Undang-Undang Presiden Dan Wakil Presiden Measuring the Democratization Degree According To Law Number 42 of 2008 Concerning General Election of the President and Vice President," no. 42 (2014): 556-571. to this decision, there are other Constitutional Court decisions that question the Presidential threshold, including the Constitutional Court Decision Number 51-52-59/PUU-VI/2008. In this decision, according to the Constitutional Court, the threshold setting contained in Article 9 of Law Number $42 / 2008$ is a concrete norm which is the elaboration of Article 6A Paragraph (2) of the 1945 Constitution.

The policy on the requirement of $20 \%$ (twenty percent) of the seats in the House of Representatives or $25 \%$ (twenty-five percent) of the national valid votes in the Election of the House of Representatives, as the opinion of the Court in previous decisions, is an open legal policy which is delegated by Article 6A Paragraph (5) of the 1945 Constitution which stipulates that "The procedure for conducting the election of President and Vice President shall be further regulated in law", and Article 22E Paragraph (6) of the 1945 Constitution which stipulates, "Further provisions concerning general elections shall be regulated by law".

According to the Constitutional Court, regarding the absence of democratic, direct, general, free, confidential, honest and fair elections, there is no logical correlation between the requirement of $20 \%$ (twenty percent) of the House of Representatives seats or 25\% (twentyfive percent) of the national valid votes which must be obtained by a Party to nominate the Candidate Pairs for President and Vice President with the democratic, direct, general, free, confidential, honest and fair elections.

Instead, the party's achievement of these conditions is obtained through a democratic process that is handed over to the sovereign electorate. This is also to prove whether the party that nominates the Presidential and Vice-Presidential Candidates has broad support from the electorate. Moreover, the Constitutional Court is of the opinion that regarding the requirement that a political party or a coalition of political parties must obtain support of $20 \%$ (twenty percent) of the seats in the House of Representatives or $25 \%$ (twenty-five percent) of the national valid votes before the presidential general election, according to the Court, this support is initial support. Meanwhile, the actual support will be determined by the results of the Presidential and Vice-Presidential Elections. The Presidential and Vice-Presidential Candidates who 
will become the Government since the beginning of their nomination have been supported by the people through political parties that have obtained certain support through elections.

In addition to the Constitutional Court Decision Number 51-52-59/PUU-VI/2008 related to the decision that questioned the Presidential threshold, there is also Constitutional Court Decision Number 53/PUU-XV/2017 which says that the presidential threshold provision in Article 222 of Law Number 7 Year 2017 concerning General Elections is the manipulation and tug of war on the political interests of parties supporting the government, opposition parties, and the government, given the number of factions in the House of Representatives who walked out when the decision-making regarding the Law of General Election was passed.

The Constitutional Court is of the opinion that the making of a law is a political decision from a political process of state institutions which are authorized by the Constitution to make laws, in this case the House of Representatives together with the President. Therefore, the Constitutional Court is not authorized to assess the political practices and political dynamics that occur during the process of making a law as long as the procedure for making the said law does not conflict with the procedures specified in the 1945 Constitution.

In particular, as regulated in Article 20 Paragraph (2), Paragraph (3), Paragraph (4) and Paragraph (5) of the 1945 Constitution, the existence of a number of factions who walked out does not cause the substance or content material of a Law to be unconstitutional, but only shows the level of acceptance of the content material of the law in question. In the sense that approval of the content material of the Law is not obtained by acclamation.

The presidential threshold provision in Article 222 of the Election Law which has been used in the 2014 Election is irrelevant and out of date when applied in the 2019 simultaneous elections. the Constitutional Court is of the opinion that the Law governing the 2014 Election is not Law Number 7 Year 2017 concerning General Elections, but Law Number 8 Year 2012 which does not or has not enforced the provisions regarding the presidential threshold, in the process of nominating the pairs of Presidential and Vice-
Presidential Candidates. After all, how can a law that was born later be said to have expired due to a situation or event that occurred earlier that was subject to a different law?

Furthermore, the presidential threshold provision in Article 222 of the Election Law contradicts the logic of the simultaneous election of 2019, namely that the elections for members of the House of Representatives, the Regional Representative Council, and the Regional House of People's Representative are held simultaneously with the Presidential and Vice-Presidential Elections, as stated in the Constitutional Court Decision Number 14/PUU-XI/2013. The Court is of the opinion that the Constitutional Court in its previous decision, namely the Constitutional Court Decision Number 51-52-59/PUU-VI/2008, dated February 18, 2009, in the review of Law Number 42 Year 2008 concerning General Elections (Law Number 42 Year 2008), has emphasized that determining the minimum threshold of votes acquisition for political parties (or a coalition of political parties) to be able to nominate candidates for President and Vice President is the legal policy of the legislature.

The affirmation of the opinion of the Constitutional Court was then again based on the Constitutional Court Decision Number 5152-59/PUU-VI/2008, that the legal consideration regarding the minimum threshold of votes acquisition for political parties (or coalitions of political parties) in order to nominate the Presidential and Vice-Presidential Candidates (which at that time was regulated in Article 9 of Law Number 42 Year 2008) is a law-making policy (legal policy).

It is in no way associated with the existence of a norm of Law that regulates the separation of the holding of the Election to elect the President and Vice President from the Election to elect members of the House of Representatives, the Regional Representative Council, and the Regional House of People's Representative (as regulated in Article 3 paragraph (5) of Law Number 42 Year 2008), which was also requested for a constitutional review at that time. The theoretical argument for the constitutionality of requirements regarding the minimum threshold of votes acquisition for political parties (or coalitions of political parties) to be able to nominate candidates for President and Vice President is not derived from the logic 
of unifying or separating the Election to elect the President/Vice President with/from the Election to elect members of the House of Representatives, the Regional Representative Council, and the Regional House of People's Representative. Rather, it is from a theoretical argument to strengthen the Presidential system in the sense of realizing a system and practice of government that is closer to the ideal characteristics/requirements of a Presidential system of government so that it prevents the practices that actually show the characteristics of a Parliamentary system.

The presidential threshold provision in Article 222 of the Election Law undermines the Presidential system and eliminates the function of evaluating the implementation of the Election. The Court's considerations as described in number 1 to 5 above have confirmed that the provisions contained in Article 222 of the Election Law are in fact in accordance with the idea of strengthening the Presidential system which is the constitutional design of the 1945 Constitution. Meanwhile, if what is meant by "eliminating the evaluation of the implementation of elections". The Petitioner assumed there was people's dissatisfaction with the performance of the House of Representatives and the President and Vice President who were elected in the 2014 Election, with the assumption that the people would be faced with the same pair of Presidential and Vice-Presidential Candidates who would compete in the 2019 Election as affirmed by the Petitioner in his Petition. This assumption was too premature because it was not certain that the pairs of Presidential and VicePresidential Candidates who would compete in the 2019 Election are the same pairs of Presidential and Vice-Presidential Candidates who were contesting in the 2014 Election. This assumption would only be proven post factum. Moreover, even if this assumption is true, quod non, it does not necessarily make the norms contained in Article 222 of the Election Law unconstitutional.

Regarding the issue of the presidential threshold, there is similarity in the legal considerations of judges of the Constitutional Court in the Decision of the Constitutional Court Number 51-52-59/PUU-VI/2008, and Decision of the Constitutional Court Number 53/PUU$\mathrm{XV} / 2017$ that the determination of the minimum threshold of votes acquisition for political parties (or coalitions of political parties) to be able to nominate candidates for President and Vice President as a law-making policy (legal policy). Then, this matter is in no way associated to the existence of a norm of Law that regulates the separation of the implementation of the General Election to elect the President and Vice President from the Election to elect members of the House of Representatives, the Regional Representative Council, and the Regional House of People's Representative.

\section{B. The Paradigm of Incompatibility between the Conception of Simultaneous General Election and Presidential Threshold}

Before further discussing the issue of incompatibility between the conception of simultaneous general election and presidential threshold, it is better to describe the purpose of each of these conceptions first. Thus, the explanation that will be carried out on the compatibility between the two concepts will be easier to show.

Referring to Sodikin's opinion, the presidential threshold is setting the threshold level of support from the House of Representatives. Both in terms of the number of votes (ballot) or the number of seats that must be obtained in order to nominate the President and/or Vice President ${ }^{39}$. Based on this definition, it can be seen that the presidential threshold aims to determine a number of parties that can nominate candidates for President and/or Vice President.

Thus, it will be coherent with another logical consequence, namely the need for coalition with other parties. Therefore, if the parties that win the minority votes cannot get a coalition, then these parties will automatically move away from the existing political contestation and die by themselves.

Therefore, the existence of the conception of presidential threshold is very obvious in the spirit of simplifying the number of parties in the presidential system. Although, the existence of these supporting political parties does not have direct ties, for example in the form of the ability/ authority to overthrow the current President and/ or Vice President.

Such thing can only happen in countries that adhere to a parliamentary system. Such a thing can happen because conceptually in the government

39 Ibid. 
system there is no fixed term of office. In addition, the government is also a member of parliament. So that the parliament can have control which in this case is up to the limit of being able to overthrow the ruling government.

Meanwhile, in a presidential government system there is no relationship between the parliament/legislature and the government/ executive, as described in the description in the previous paragraph on the parliamentary government system. It further emphasizes that the existence of the conception of presidential threshold is solely for the purpose of simplifying the number of parties.

Table 3. The Comparison of Simultaneous General Elections

\begin{tabular}{|c|c|c|}
\hline \multirow{2}{*}{ Country } & \multicolumn{2}{|c|}{ Simultaneous General Elections } \\
\hline & National & Implication \\
\hline Indonesia & $\begin{array}{l}\text { Election of } \\
\text { the President, } \\
\text { the House of } \\
\text { Representatives } \\
\text { and the Regional } \\
\text { Representative } \\
\text { Council }\end{array}$ & $\begin{array}{l}\text { The implication for the } \\
\text { Coattail Effect is that } \\
\text { the parties elected in the } \\
\text { Presidential Election } \\
\text { tend to be elected in the } \\
\text { Legislative Election. } \\
\text { There is a possibility } \\
\text { that the winner of the } \\
\text { Legislative Election is the } \\
\text { political party that wins the } \\
\text { Presidential Election. }\end{array}$ \\
\hline Brazil & $\begin{array}{l}\text { Election of the } \\
\text { President and } \\
\text { the National } \\
\text { Congress of } \\
\text { Brazil. }\end{array}$ & $\begin{array}{l}\text { The implication for the } \\
\text { Coattail Effect is that } \\
\text { the victory of the elected } \\
\text { President is followed by } \\
\text { the victory of the coalition } \\
\text { of political parties that } \\
\text { nominate him/her in the } \\
\text { competition for seats in } \\
\text { the legislative elections. } \\
\text { The government will } \\
\text { work effectively because } \\
\text { the President has the } \\
\text { full support from the } \\
\text { Parliament. }\end{array}$ \\
\hline
\end{tabular}

This is in contrast to the conception of a simultaneous general election as initiated by Brazil in $1994^{40}$, where the application of the conception of a simultaneous general election is an effort to stimulate an impact known as the coattail effect ${ }^{41}$. The coattail effect, or what in Bahasa Indonesia is called as efek menarik kerah, is an expected

\footnotetext{
40 Kementerian Dalam Negeri, Naskah Akademik Rancangan Undang-Undang Tentang Penyelenggaraan Pemilihan Umum, September 2016, hal. 42.

${ }_{41}$ Ibid.
}

impact from the implementation of the concept of simultaneous general elections in countries with presidential systems.

It is hoped that through the simultaneous general election, the voters will vote the President and/or Vice President who has the best track record and popularity and then vote the supporting political parties as well ${ }^{42}$. This is what is known as the coattail effect.

Furthermore, based on the characteristics of the objective of the conception of the simultaneous general election, it can be seen that it is also aimed at establishing a stable relationship between the government and parliament, where the coattail effect as described previously will lead to a parliamentary condition that contains the majority of members of political parties supporting the elected President and/or Vice President.

Referring to the opinion of Didik Supriyanto, by reflecting his opinion on the experience in Brazil which has shown the success of the coattail effect as referred to in the simultaneous general election. When the voters in Brazil were presented with presidential election ballots and party election ballots, the voters tended to vote the party that supported the President they voted ${ }^{43}$.

Such condition indicates that the conception of a simultaneous general election system aims to streamline election time. Then, apart from that, it aims to encourage the establishment of good executive/state government performance through a stable relationship with the parliament. The stability is obtained through efforts to fill the parliament which leads to the occupation of the majority by the parties that support the elected government.

Efforts to encourage the filling of parliament with the majority of members of the political parties supporting the President are achieved by fair efforts through the framework of the coattail effect resulted from the mechanization of simultaneous general elections. Because, it should be emphasized that in a presidential system the position of the government/executive is very significant in running the wheels of government.

The condition of the occupation of the President based on the concept of fixed terms of office makes it difficult for the President to

42 Ibid.

43 Ibid 
be overthrown by the parliament/legislature of a country. Although current developments have resulted in a concept known as impeachment/ declaration of incapacity, in order to overthrow incompetent government/executives or the government/executives who are no longer qualified.

The steps that need to be taken in achieving the goal of overthrowing the government/ executives through impeachment/declaration of incapacity are not an easy path. Therefore, in the end, the conception of fixed terms of office remains consequently attached to the presidential system of government.

However, even though Brazil in the early days of implementing the concept of simultaneous general elections showed success, referring to its development today, especially the period of Dilma Roessef's administration, Brazil has brought about a new paradox in the application of the concept of simultaneous general elections ${ }^{44}$.

The paradox arose through the factual conditions of instability of the Brazilian government during the leadership of Dilma Roessef itself. Where, Dilma Roessef, who is also the first female President in Brazil, actually stepped down from her office, even though it resulted from the simultaneous general election in $2014^{45}$.

The paradox of the failure of the simultaneous general election that occurred during the leadership of Dilma Roessef can be elaborated into several variables/causing factors as described by Usep Hasan Sadikin which include ${ }^{46}$ :

a. There are too many seats in each constituency.

Each constituency in Brazil has 8-70 seats. Too many seats in one constituency will result in many parties in parliament. According to the results of the 2014 Brazilian general election, the parties supporting Dilma only won $70 / 513(13 \%)$ seats. The other $87 \%$ of seats must be shared with the 27 parties in parliament.

b. Legislative elections are conducted for legislative candidates and not parties.

\footnotetext{
44 Usep Hasan Sadikin, "Paradoks Pemilu Serentak Brasil," last modified 2016, https://rumahpemilu.org/ paradoks-pemilu-serentak-brasil/.

45 Ibid.

46 Ibid.
}

The implementation of a candidate-list/ open-list proportional representation general election system. This open-list proportional system is not effective in optimizing the coattail effect of simultaneous general elections. If the voters are offered the choice of the President and the party's choice includes a list of legislative candidates, then there is a tendency that the presidential choice is not in accordance with the choice of the party that nominates the President because the voters choose legislative candidates based on the quality of the legislative candidates, not the quality of the party/president. This tendency persists even though the general election is simultaneous.

c. Two-round Presidential election.

Brazil implemented a presidential election system based on a majority run off. The tworound presidential election, in simultaneous general elections, tends to reduce the possibility of the emergence of a majority party in parliament. The hopes of the coalition of parties to occur early and permanently were also delayed because the parties and presidential candidates were more focused on how to advance to the second round.

Although the implementation of the simultaneous general election encountered such an anticlimax, the obstacles to achieving the goals of simultaneous general elections are not insurmountable. The solution that can be taken is simple; taking steps that are the opposite of the policy taken by Brazil.

In addition, of course, other steps can still be taken to produce an alternative solution in order to avoid the anticlimax in implementation of the simultaneous general election as happened in Brazil in the Dilma Roessef era.

The comparison of the objectives between the conception of presidential threshold and simultaneous general elections, as described in the previous paragraphs, increasingly shows that the two concepts are different things. Even if the presidential threshold is to be implemented, then the legislative general election must be carried out before the executive general election is held.

Of course, this is done in order to determine the initial support of political parties that are entitled to nominate pairs of candidates for 
President and/or Vice President. This is important, referring to the opinion of Asep Wijaya et.al where he states that the presidential threshold then becomes a complicated thing because politics is a dynamic thing ${ }^{47}$. This dynamic occurs because a party's vote acquisition in a general election will not necessarily be the same in another general election in the coming years ${ }^{48}$. Therefore, it is very unreasonable to apply the conception of presidential threshold in the same frame as the implementation of simultaneous general elections.

In addition, the experience of countries with presidential systems that also apply the concept of simultaneous general elections such as America, Brazil, Peru, Mexico, Colombia, and Kyrgyzstan, which in the simultaneous general elections do not recognize the presidential threshold ${ }^{49}$, shows that the incompatibility of the unification of the concept of presidential threshold and the simultaneous general election is getting stronger.

Table 4. The Provisions of Presidential Threshold in Countries with Presidential System

\begin{tabular}{|l|l|}
\hline \multicolumn{1}{|c|}{ Country } & \multicolumn{1}{|c|}{ Presidential Nomination Provisions } \\
\hline $\begin{array}{l}\text { United States } \\
\text { of America }\end{array}$ & $\begin{array}{l}\text { As a country with the most established } \\
\text { Presidential Threshold system, there } \\
\text { is no threshold provision in the 1992 } \\
\text { Constitution of the United States }\end{array}$ \\
\hline Brazil & $\begin{array}{l}\text { Chapter V of the 2017 Brazilian } \\
\text { Constitution on Political Parties does not } \\
\text { regulate nor mention at all the threshold } \\
\text { for nominating presidential candidates. } \\
\text { Each party has the freedom to nominate a } \\
\text { presidential candidate. }\end{array}$ \\
\hline Peru & $\begin{array}{l}\text { Chapter IV of the 2021 Peruvian } \\
\text { Constitution on the Branches of Executive } \\
\text { Power does not regulate the threshold for } \\
\text { presidential nomination. }\end{array}$ \\
\hline
\end{tabular}

${ }^{47}$ Asep Wijaya, dkk, "Problematika Hukum Penerapan Presidential Threshold Dalam Pemilihan Umum Di Indonesia., Risalah Hukum, Vol. 16, No. 1, Juni 2020, hlm. 46 .

${ }^{8}$ Wijaya and Erwinta, "Problematika Hukum Penerapan Presidential Threshold Dalam Pemilihan Umum Di Indonesia."

49 Abdul Ghoffar, "Problematika Presidential Threshold : Putusan Mahkamah Konstitusi Dan Pengalaman Di Negara Lain Dispute on Presidential Threshold: Decisions of the Constitutional Court and Other Countries ' Experiences.", Jurnal Konstitusi, Vol. 15, No. 3, September 2018, hlm. 498.

\begin{tabular}{|l|l|}
\hline \multicolumn{1}{|c|}{ Country } & \multicolumn{1}{|c|}{ Presidential Nomination Provisions } \\
\hline Mexico & $\begin{array}{l}\text { Article 82 Chapter III of the 2015 } \\
\text { Mexican Constitution on Federal } \\
\text { Executive Powers does not mention nor } \\
\text { regulate the threshold for presidential } \\
\text { nomination. }\end{array}$ \\
\hline Kyrgyzstan & $\begin{array}{l}\text { Article 62 paragraph (2) of the 2010 } \\
\text { Kyrgyzstan Constitution states that there } \\
\text { is no limit to the number of presidential } \\
\text { candidates. A candidate who has collected } \\
\text { more than 30,000 vote signatures can } \\
\text { register as a presidential candidate. }\end{array}$ \\
\hline
\end{tabular}

The application of the conception of presidential threshold can also encourage the movement of the level of democracy as stated by Dahl. In his opinion, Dahl argues that democratization is shaped by two dimensions, namely public contestation and the right to participate ${ }^{50}$. The combination of these two dimensions will produce at least 4 (four) variants of democracy which can be illustrated as follows ${ }^{51}$ :

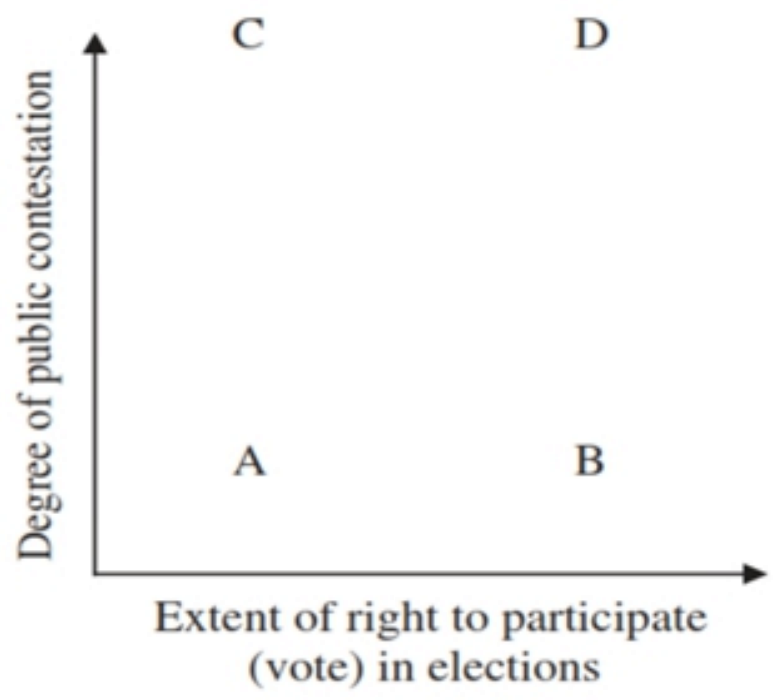

Figure 1. Dahl Democratic Axis

Dahl uses the axis of analysis which then leads to 4 (four) forms of political systems as follows: ${ }^{52}$

a. [C] Competitive Oligarchy

High political contestation, the right to vote is limited to certain classes.

b. [A] Closed Hegemony

Low political contestation, the right to vote is limited to a certain number of classes.

\footnotetext{
${ }^{50}$ Albert H.Y. Chen, "The Law and Politics of the Struggle for Universal Suffrage in Hong Kong, 2013-15," Asian Journal of Law and Society 3, No. 1 (2016): 189-207.

${ }^{11}$ Ibid.

52 Ibid.
} 
c. [D]Polyarchy

High political contestation, the right to vote applies to people in general.

\section{d. [B] Inclusive Hegemony}

Low political contestation, the right to vote is extended/applies to people in general.

Referring to Dahl's opinion, the coherence between the presidential threshold and the political system will facilitate a country's political system to move towards the closed hegemony form or only inclusive hegemony. Of course, this is not expected to happen in Indonesia.

\section{The Possibility of Violation of the Constitutional Rights of Citizens in relation to the Implementation of the Conception of Presidential Threshold}

Apart from the incompatibility between the application of the conception of presidential threshold and the application of the conception of simultaneous general election, apparently, there is also a number of views on the possibility of violation of constitutional rights of citizens on the implementation of the conception of presidential threshold.

The State of Indonesia recognizes and protects the right of every citizen to take part in the implementation of public affairs, the right to vote and the right to be elected as stated in Article 25 of Law Number 12 Year 2005 concerning Ratification of the International Covenant on Civil and Political Rights. This covenant affirms the principles of human rights in the civil and political fields contained in the Declaration of Human Rights (Universal Declaration of Human Rights) $)^{53}$.

It is known that election activities are a means for citizens to exercise their human rights in principle ${ }^{54}$. The fulfillment of citizens' rights to actively participate in the implementation of elections is one of the benchmarks for election success $^{55}$. In addition, this view was also conveyed

53 Hilmi Ardani Nasution and Marwandianto, "Memilih Dan Dipilih, Hak Politik Penyandang Disabilitas Dalam Kontestasi Pemilihan Umum: Studi Daerah Istimewa Yogyakarta," Jurnal HAM 10, no. 2 (2019). Hal 186

54 Bawamenewi, "Implementasi Hak Politik Warga Negara," Journal of Chemical Information and Modeling 53, no. 9 (2013). Hal 38

55 Wiguna, "Pentingnya Prinsip Kebijaksanaan by Asep Wijaya with the complete information as follows:

"Based on the 1945 Constitution, there are provisions regarding the rights of citizens which can be seen in Article 27 Paragraph (1) which explains the rights of citizens to vote which is contained in the rights of citizens guaranteed by the constitution in the form of equality in law and government. In addition, Article 28D Paragraph (1) explains the right to obtain fair recognition, guarantee, protection, and legal certainty as well as equal treatment before the law. Article $28 \mathrm{D}$ Paragraph (3) also explains the right to obtain equal opportunities in government. The rules regarding human rights are a form of embodiment of people's sovereignty as regulated in Article 1 Paragraph (2) and Article 6A Paragraph (1). ${ }^{56}$ "

Every citizen has the right to be actively involved in political life. If we refer to the various laws and regulations governing political rights, there is not a single rule that is discriminatory ${ }^{57}$. The researchers has the same opinion on the alleged constitutional disadvantage of equal opportunity in government. The existence of the conception of presidential threshold, of course, will encourage public's low political contestation. In fact, in the extreme illustration as described by Dahl, it can take the form of Inclusive Hegemony ${ }^{58}$.

In addition, it is irrelevant if the determination of political parties which can nominate candidates for President and/or Vice President during the election period is based on the votes acquisition of the political party concerned in the result of election of the previous period. In fact, when referring to the opinion of Asep Wijaya, politics is a dynamic thing.

Regarding the limitation of the constitutional rights of citizens to have equal opportunities in government, of course, it will lead to the concretization of one's political rights to be elected in public political contestations, where the political rights are also part of human rights.

Berdasarkan Pancasila Dalam Kehidupan Hukum Dan Demokrasi Indonesia." Hal 736

${ }_{56}$ Wijaya and Erwinta, "Problematika Hukum Penerapan Presidential Threshold Dalam Pemilihan Umum Di Indonesia."

57 Nasution and Marwandianto, "Memilih dan Dipilih, Hak Politik Penyandang Disabilitas Dalam Kontestasi Pemilihan Umum: Studi Daerah Istimewa Yogyakarta."

${ }^{8}$ Chen, "The Law and Politics of the Struggle for Universal Suffrage in Hong Kong, 2013-15."hal 201 
Therefore, the limitation of these rights should be based on universally recognized principles.

Referring to the general acknowledgment of the limitation/negation of human rights, there are at least two principles used in doing such matter. Namely, the Siracusa and Camden Principles. Referring to the opinion of the United Nations, it is concluded that the application of the Siracusa Principles must be in the following corridors ${ }^{59}$ :

a. Established by law;

b. In a democratic society;

c. Public order;

d. Public health;

e. Public morals;

f. National security;

g. Public safety;

h. The rights and freedom of others or the rights and reputation of others; and

i. Restrictions on general courts.

Furthermore, Halili states that the existence of the Siracusa Principle will provide an operational interpretation of the limitation of human rights ${ }^{60}$. This means that the implementation of human rights can be limited as long as it can be accounted for fulfilling the indicators of the Siracusa Principle.

In addition, Wiratraman provides a definition of the Siracusa Principle as an explanation that restrictions must be formulated strictly for the interest of the protected rights and consistent with the objectives of the ICCPR provisions, so that these restrictions should not be carried out arbitrarily and without valid reasons. These restrictions must be clearly formulated and accessible to everyone and provide safeguards and redress against the impact and application of restrictions that are illegal and prone to be abused.

Then, Wiratraman also explains the Camden Principle and says that the state should not impose restrictions on freedom of expression that are not in line with the standards set out in Principle 3.2. and, the applicable restrictions should be regulated by law, are intended to protect the rights or

59 Pasal 22 ayat (2) Kovenan Internasional tentang HakHak Sipil dan Politik

60 Halili, "UU No. 1/PNPS/1965 Dan Tafsir Pembatasan Kebebasan Beragama/Berkeyakinan Di Indonesia," Jurnal HAM XI, No. Kebebasan Beragama dan Berkeyakinan (2014): 93-112. reputation of others, or public health and morals, and are required by democratic societies to protect those interests ${ }^{61}$.

It seems that the application of the presidential threshold principle can be seen as something that is still in line with the principles of a democratic society. However, referring to the fact that the concept of presidential threshold is not compatible with the conception of simultaneous general election, the implementation of the presidential threshold should be seen as irrelevant to the needs of a democratic society and considered as a form of violation of constitutional rights which are also human rights.

\section{CONCLUSION}

In the implementation of general elections in Indonesia, especially since 2019, the adoption of the concept of simultaneous general election on the one hand and the provision of presidential threshold which still applies on the other hand, have shown the incompatibility between one another. The existence of the provision of presidential threshold is basically expected to simplify the number of parties. However, in reality, the implementation of simultaneous general elections caused a coattail effect, where when voting a presidential candidate, voters tend to vote the political party that nominates the president they vote. In addition, the presidential threshold which still applies can also push the Indonesian political system into a purely inclusive hegemony, where the granting of the right to vote is carried out widely, but political involvement or contestation is limited in such a way so that it has low value.

\section{SUGGESTION}

Should Indonesia still choose to hold simultaneous elections, it would be better for the legislature to exclude the provision of presidential threshold in making the rules of the implementation of simultaneous election. This is because the two concepts are incompatible and contradictory. In addition, the abolition of the presidential threshold will certainly provide an opportunity for every citizen, especially those who do have the capacity and capability to participate directly in general elections.

61 Paulus Suryanta Ginting, Issay Wenda, and Ambrosius Mulait, "Kebebasan Ekspresi dan Makar Dalam Sistem Hukum Ham," no. 1304 (2020): 1-22. 


\section{ACKNOWLEDGEMENT}

The researchers would like to convey praise and gratitude to God Almighty. Because of His abundance of power, the researchers can complete this paper. The researchers would like to thank the Research and Development Board for Law and Human Rights and the parties who have provided support in the writing of this paper.

\section{BIBLIOGRAPHY}

Abdurrohman. "Presidential Threshold Dalam Pemilu Di Indonesia, Perspektif Imam AlMawardy." Universitas Islam Negeri Sunan Ampel, 2018.

Ansori, Lutfil. "Telaah Terhadap Presidential Threshold Dalam Pemilu Serentak 2019" 4, no. 1 (2019).

Ariviani, Rubian, Hasyim Asy, Untung Sri Hardjanto, Program Studi, S Ilmu, Fakultas Hukum, and Universitas Diponegoro. "Analisis Putusan Mahkamah Konstitusi Nomor 14/Puu-Xi/2013 Berkaitan Dengan Pemilihan Umum Serentak Di Indonesia." Diponegoro Law Review 5, no. 4 (2016).

Asshiddiqie, Jimly. Hukum Tata Negara Dan Pilar-Pilar Demokrasi. Jakarta: Sinar Grafika, 2011.

Bawamenewi. "Implementasi Hak Politik Warga Negara." Journal of Chemical Information and Modeling 53, no. 9 (2013).

Chen, Albert H.Y. "The Law and Politics of the Struggle for Universal Suffrage in Hong Kong, 2013-15." Asian Journal of Law and Society 3, no. 1 (2016).

Gai, Apolonaris, and Frans Bapa Tokan. "Analisa Dampak Penyelenggaraan Pemilu Serentak Dalam Meningkatkan Kualitas Demokrasi Di Indonesia: Studi Kasus Penyelenggraan Pemilu Di Kota Kupang-Provinsi Nusa Tenggara Timur Tahun 2019." Warta Governare: Jurnal Ilmu Pemerintahan 1 (2020).

Ghoffar, Abdul. "Problematika Presidential Threshold: Putusan Mahkamah Konstitusi Dan Pengalaman Di Negara Lain Dispute on Presidential Threshold: Decisions of the Constitutional Court and Other Countries
' Experiences." Jurnal Konstitusi 15, no. 3 (2018).

Ginting, Paulus Suryanta, Issay Wenda, and Ambrosius Mulait. "Kebebasan Ekspresi Dan Makar Dalam Sistem Hukum Ham," no. 1304 (2020).

Halili. "UU No. 1/PNPS/1965 Dan Tafsir Pembatasan Kebebasan Beragama/ Berkeyakinan Di Indonesia." Jurnal HAM XI, no. Kebebasan Beragama dan Berkeyakinan (2014).

Ibrahim, Gibran Maulana. "Tolak Presidential Threshold, Demokrat: Membatasi Capres Alternatif." Last modified 2017. https:// news.detik.com/berita/d-3567236/tolakpresidential-threshold-demokrat-membatasicapres-alternatif.

Indonesia, Republik. Undang-Undang Nomor 23 Tahun 2003 Tentang Pemilihan Umum Presiden Dan Wakil Presiden, 2003.

Kristiyanto, Eko Noer. "Pelaksanaan Pemilihan Kepala Daerah Serentak Di Indonesia: Studi Di Batam." Jurnal Penelitian Hukum De Jure 17, no. 1 (2017).

Made, I Dewa, and Putra Wijaya. "Mengukur Derajat Demokrasi Undang-Undang Presiden Dan Wakil Presiden Measuring the Democratization Degree According To Law Number 42 of 2008 Concerning General Election of the President and Vice President," no. 42 (2014).

Manan, Bagir. "Penelitian Terapan Di Bidang Hukum", (Disampaikan Pada Lokakarya Peranan Naskah Akademis Dalam Penyusunan Peraturan PerundangUndangan)." Badan Pembinaan Hukum Nasional, Jakarta (1993).

Nasution, Hilmi Ardani, and Marwandianto. "Memilih Dan Dipilih, Hak Politik Penyandang Disabilitas Dalam Kontestasi Pemilihan Umum: Studi Daerah Istimewa Yogyakarta." Jurnal HAM 10, no. 2 (2019).

Noviati, C. "Demokrasi dan Sistem Pemerintahan." Jurnal Konstitusi 10, no. 2 (2013).

Oki Wahju Budijanto. "Pemenuhan Hak Politik Warga Negara Dalam Proses Pemilihan 
Kepala Daerah Langsung.” Jurnal Penelitian Hukum De Jure 16 (2016).

Peter Mahmud Marzuki. Penelitian Hukum. Jakarya: Kencana, 2010.

Purwaningsih, Septi Nur Wijayanti dan Titin. Laporan Akhir Tahun Pertama Penelitian Hibah Bersaing: Desain Pemilihan Umum Nasional Serentak Dalam Perspektif Hukum Dan Politik, 2015.

Sadikin, Usep Hasan. "Paradoks Pemilu Serentak Brasil." Last modified 2016. https:// rumahpemilu.org/paradoks-pemilu-serentakbrasil/.

Sinamora, Jantapar. "Menyongsong Rezim Pemilu Serentak." Jurnal RechtsVinding 3, no. 4 (2019).

Solihah, Ratnia. "Peluang Dan Tantangan Pemilu Serentak 2019 Dalam Perspektif Politik." Jurnal Ilmiah Ilmu Pemerintahan 3 (2018).

Subiyanto, Achhmad Edy. "Pemilihan Umum Serentak Yang Berintegritas Sebagai Pembaruan Demokrasi Indonesia." Jurnal Konstitusi 17 (2020).

Sukimin, Sukimin. "Pemilihan Presiden Dan Wakil Residen Berdasarkan Undang-Undang Republik Indonesia Nomor 7 Tahun 2017 Tentang Pemilihan Umum." Jurnal Usm Law Review 3, no. 1 (2020).

Syaifulloh. "Kesadaran Pluralisme Dalam Praktik Demokrasi Pancasila." Jurnal IDe (Inspirasi Demokrasi) Vol. 08 (2019).

Toriana, Lia. "Pemilu Serentak Dan Politik Massa: Belajar Dari Brasil." Last modified 2014. https://rumahpemilu.org/pemilu-serentakdan-politik-massa-belajar-dari-brasi1/.

Wagay, Bashir Ahmad. "Simulatenous Elections and India Democracy: A Hanging Fruit Requiring Safer Handsto Pluck It".” Scholarly Research Journal for Interdisciplinary Studies 9, no. 44 (2018): 10162-10163.

Wiguna, Made Oka Cahyadi. "Pentingnya Prinsip Kebijaksanaan Berdasarkan Pancasila Dalam Kehidupan Hukum Dan Demokrasi Indonesia." Jurnal Ilmiah Kebijakan Hukum Volume 15, no. 1 (2021).
Wijaya,Asep, and Poppilea Erwinta. "Problematika Hukum Penerapan Presidential Threshold Dalam Pemilihan Umum Di Indonesia" 16, no. 2 (2020).

Yuliyanto, Yuliyanto. "Transformasi Model Pelaksanaan Pemilihan Kepala Daerah Serentak." Jurnal Penelitian Hukum De Jure 17, no. 1 (2017) 